Med Princ Pract 2017;26:98-99

DOI: $10.1159 / 000452335$

\section{Heart Rate Variability, Heart Rate Recovery, and Heart Rate Turbulence Represent Different Components of the Cardiac Autonomic Nervous System}

Mustafa Gulgun

Division of Pediatric Cardiology, Department of Pediatrics, Gulhane Military Medical Academy, Ankara, Turkey

Dear Editor,

I read with great interest the paper by Yilmaz et al. [1] entitled 'Assessment of the Cardiac Autonomic Nervous System in Mercury-Exposed Individuals via Post-Exercise Heart Rate Recovery'. They aimed to investigate cardiac autonomic function in mercuryexposed individuals by exercise heart rate recovery. They demonstrated lower heart rate recovery indices in the mercury-exposed patients, implying that there was cardiac autonomic dysfunction in these patients.

Cardiac autonomic dysfunction is an independent cardiovascular risk factor and can be evaluated by noninvasive methods such as heart rate variability, heart rate turbulence, or heart rate recovery [2-4]. One of the best noninvasive approaches to assess cardiac autonomic function is to analyze heart rate variability defined as the oscillation of the interval between successive $\mathrm{R}$ waves on the ECG between beats. Hence, heart rate variability provides numerical data about the cardiac autonomic function [3]. Heart rate recovery is defined as the difference between maximum heart rate and heart rate during the first minute of the recovery period after treadmill stress testing. A difference $\leq 12$ beats is considered an abnormal response of the cardiac autonomic function [4]. Heart rate turbulence is the measurement of turbulence onset and turbulence slope according to an algorithm, and describes the return of the heart rate to equilibrium after a premature ventricular contraction [1]. Impairments on heart rate variability, heart rate turbulence, or heart rate recovery are associated with a greater risk of mortality [1-5]. However, these parameters of heart rate variability, heart rate recovery, and heart rate turbulence stand for different components of cardiac autonomic function. Heart rate variability represents the spontaneous activity of cardiac autonomic function. Heart rate turbulence is used for evaluation of the spontaneous response of baroreflex receptor activity against stress. Heart rate turbulence shows the recovery of parasympathetic tonus after maximal treadmill stress testing [2-5]. Piotrowicz et al. [5] reported that 8-week physical training in patients with heart failure changed the heart rate variability indices without significantly altering the indices of heart rate recovery or heart rate turbulence, indicating that various mechanisms affected the parameters of heart rate variability, heart rate recovery, and heart rate turbulence.

I think the discussion of outcomes in the study by Yilmaz et al. [1] might have been more useful if the authors had considered the remarkable difference among heart rate variability, heart rate recovery, and heart rate turbulence measurements. Moreover, it would have been more helpful to perform the study using the combination of heart rate variability, heart rate recovery, and heart rate turbulence for a clearer determination of the mechanism of impairment of cardiac autonomic function in the mercury-exposed individuals.

\section{References}

1 Yilmaz OH, Karakulak UN, Tutkun E, et al: Assessment of the cardiac autonomic nervous system in mercury-exposed individuals via post-exercise heart rate recovery. Med Princ Pract 2016;25:343-349.

2 Rolim LC, Sá JR, Chacra AR, et al: Diabetic cardiovascular autonomic neuropathy: risk factors, clinical impact and early diagnosis. Arq Bras Cardiol 2008;90:24-31.

3 Gülgün M, Fidancı MK: Heart rate variability can be affected by gender, blood pressure, and insulin resistance. Anatol J Cardiol 2015;15:262263.

4 Barbosa Lins TC, Valente LM, Sobral Filho DC, et al: Relation between heart rate recovery after exercise testing and body mass index. Rev Port Cardiol 2015;34:27-33.

5 Piotrowicz E, Baranowski R, Piotrowska M, et al: Variable effects of physical training of heart rate variability, heart rate recovery, and heart rate turbulence in chronic heart failure. Pacing Clin Electrophysiol 2009;32: $113-115$

\section{KARGER}

E-Mail karger@karger.com www.karger.com/mpp (c) 2016 S. Karger AG, Basel

\section{Karger}

Open access

This is an Open Access article licensed under the terms of the Creative Commons Attribution-NonCommercial 3.0 Unported license (CC BY-NC) (www.karger.com/OA-license), applicable to the online version of the article only. Distribution permitted for non-commercial purposes only.
Mustafa Gulgun, MD

Department of Pediatric Cardiology, Gulhane Education and Research Hospital General Dr. Tevfik Saglam Caddesi, No: 1

TR-06010 Etlik, Ankara (Turkey)

E-Mail mgulgun@gata.edu.tr 


\section{Reply}

Ugur Nadir Karakulak ${ }^{a}$, Omer Hinc Yilmaz ${ }^{b}$

Departments of a Cardiology and ${ }^{b} \mathrm{Clinical}$ Toxicology, Ankara Occupational Diseases Hospital, Ankara, Turkey

\section{Dear Editor,}

First, we would like to express our thanks for the valuable comment on our report entitled 'Assessment of the Cardiac Autonomic Nervous System in Mercury-Exposed Individuals via Post-Exercise Heart Rate Recovery' [1]. As previously stated, the measurement of cardiac autonomic functions with different methods will provide more information when compared with the evaluation of heart rate recovery (HRR) in individuals with mercury exposure. In addition, autonomic functions can be evaluated not only with HRR, heart rate variability (HRV), and heart rate turbulence (HRT), but also with baroreflex sensitivity, signal averaged electrocardiogram, the tilt table test, and many other methods [2]. There are many studies in the literature about the cardiac autonomic system in individuals/workers with mercury exposure, but in most of these studies HRV was used $[3,4]$. However, we evaluated another autonomic function, i.e. HRR, using an easy and simple method that did not require complex equipment. Both HRV and HRT were calculated from long-term Holter recordings and only specialized computer software was needed. However, as the author mentioned, the application of different methods at the same time could reveal a better relationship between mercury and the cardiac autonomic system. I would like to thank the author again for his valuable and inspiring comments for future studies.
Editor's Note

Only U.N. Karakulak and O.H. Yilmaz are responsible for this response.

\section{References}

1 Yilmaz OH, Karakulak UN, Tutkun E, et al: Assessment of the cardiac autonomic nervous system in mercury-exposed individuals via post-exercise heart rate recovery. Med Princ Pract 2016;25:343-349.

2 Adlan AM, Lip GY, Paton JF, et al: Autonomic function and rheumatoid arthritis: a systematic review. Semin Arthritis Rheum 2014;44:283-304.

3 Valera B, Dewailly E, Poirier P, et al: Influence of mercury exposure on blood pressure, resting heart rate and heart rate variability in French Polynesians: a cross-sectional study. Environ Health 2011;10:99.

4 Gribble MO, Cheng A, Berger RD, et al: Mercury exposure and heart rate variability: a systematic review. Curr Environ Health Rep 2015;2:304314

Ugur Nadir Karakulak, MD

Department of Cardiology

Ankara Occupational Diseases Hospital

TR-06280 Kecioren, Ankara (Turkey)

E-Mail ukarakulak@gmail.com 